\title{
Knowledge, Awareness and Attitude of Pharmacy Students towards Epilepsy in Iraq
}

\author{
Nisreen Jumaah Jebur' ${ }^{1}$, Abeer K. Jumaa', Sarah Ali Hussain ${ }^{2}$ \\ ${ }^{1}$ Assistant Lecturer, Department of Clinical Pharmacy, College of Pharmacy, University of Baghdad, \\ Baghdad, Iraq, ${ }^{2}$ Stagiaire at college of pharmacy, University of Baghdad
}

\begin{abstract}
Background: The undergraduate students in pharmacy colleges represent a well-educated group of the community according to the use of drugs and they are required to hold the appropriate knowledge of drug use and have positive attitudes toward health problems, this good knowledge about the diseases and their treatment will give good pharmacists in the future and this will reflect positively on patient knowledge, and their compliance with treatment, this due to direct contact of pharmacists with the patients.
\end{abstract}

Aim: To know the knowledge, Awareness and Attitude of a sample of Iraqi pharmacy students towards epilepsy.

Method: Cross-sectional study used a structured questionnaire validated by previous studies to collect data about knowledge, Awareness and Attitude about epilepsy from all stages of undergraduate pharmacy students, this survey involves 260 respondents from different universities in Iraq.

Results: The questionnaire was responded by 260 students. The main part of the respondents were of age group between $21-25$ years $(84.2 \%)$. The majority of the respondents were female $(67.3 \%)$, and (32.7\%) were male. Overall knowledge was moderate $(60.1 \pm 17.8)$, awareness was poor $(42.6 \pm 33.5)$ but the attitude toward epilepsy was very good $(83.3 \pm 13.1)$.

Conclusions: The results of this study showed that, majority of the students had knowledge of the disease however, the knowledge score was moderate. While Awareness score was low, we need to have focused education and efforts to increase the knowledge and awareness towards epilepsy among pharmacy students. At the same time the attitudes of pharmacy students toward epilepsy in this study was very good.

Keywords: Epilepsy, knowledge, awareness, attitude, Pharmacy students.

\section{Introduction}

Epilepsy is a chronic disorder of the brain that affects people worldwide ${ }^{(1)}$ and in all age groups ${ }^{(2)}$, Epilepsy is a syndromes characterized by unprovoked, recurring seizures and to be epileptic should have at least more than two seizures or more, It is frequent neurological

\section{Corresponding Author:}

\section{Abeer K. Jumaa}

Assistant Lecturer, Department of Clinical Pharmacy, College of Pharmacy, University of Baghdad, Baghdad, Iraq

e-mail: abeer.jomaa@copharm.uobaghdad.edu.iq illness affecting an estimated 50 million people in the world, characterized by unusual electrical activity in the brain that lead to change in the movement of the body or can affect the sensation, consciousness or behavior ${ }^{(3)}$.

In approximately $80 \%$ of patients with epilepsy, the underlying etiology is unknown. The most common causes of epilepsy are head trauma and stroke ${ }^{(4)}$.

The causes of epilepsy depending on the age, where stroke and neoplasia being the most common factors among the elderly. In younger men, traumatic brain injuries appear to influence, as do cerebral palsy and cortical structures malformations in the younger age groups ${ }^{(5)}$. 
The WHO's 2010 Global Burden of Disease study ranks epilepsy as the second most problematic neurologic disorder worldwide in terms of disabilityadjusted life years. Previous studies of the prevalence of epilepsy focused on specific regions (China, Europe, Latin America, and Arab countries) ${ }^{(6)}$.

Estimates suggest that 50-70 million people worldwide have epilepsy, and the yearly incidence is 4.6 million. global burden estimates a wide spread in populations of low- and middle-income countries (LMIC), regardless of country income, the public health burden of epilepsy carries with it high risks of disability, loneliness, economic loss, and early death ${ }^{(7)}$.

Stigma and inequity in general cause more difficulty to epileptics than the true fits. the absence of knowledge about epilepsy has been considered to be an important decided factor in the bad attitudes towards people with this clinical condition. The deficiency of knowledge about epilepsy has been exposed in a large part of the populations throughout the World ${ }^{(8)}$.

It was established that patients with epilepsy in Western societies are more prone to have problems in their education ${ }^{(9)}$, employment ${ }^{(10,11)}$, and marriage ${ }^{(12,13)}$, and this has been attributed partly to absence of knowledge, bad attitudes, and misinterpretation about the disease among patients themselves ${ }^{(14,15)}$.

The undergraduate pharmacy students constitute a well-educated section of the community regarding drugs and have the potential to generate awareness, improve concepts and influence attitudes towards the disease since they have positive attitudes toward health problems ${ }^{(16,17)}$. In the Middle East, a small number of studies ${ }^{(18,19,20)}$ have scanned the knowledge and attitudes toward epilepsy in general population, but have not done so among pharmacy students, an important group likely to form the opinion in their community and become template for others ${ }^{(21,22)}$ Therefore, it is important that they have the appropriate and updated knowledge and suitable attitude towards epilepsy and antiepileptic drugs ${ }^{(23)}$, Because the pharmacists play a vital role in the care of patients with epilepsy. The community pharmacists not only supply information to patients that help them understand their conditions and manage the treatment by giving self-care advice, but also educate patients and their families concerning the development of adherence to their therapy, and then improving health related quality of life for those patients ${ }^{(24)}$.
The aim of this study was to assess knowledge, Awareness and Attitude of pharmacy students towards epilepsy in Iraq.

\section{Method}

Study design and respondents: This descriptive cross-sectional study was performed in 17 December 2019 among pharmacy students from different universities in Iraq. The number of respondents were 260 pharmacy student.

Study instruments and collection of data: The survey questionnaire was prepared in English language after reviewing the literature for similar studies $(16,17)$ The questionnaire was framed to gather information on demographic data, knowledge, awareness and attitude towards epilepsy, then it was transferred to electronic form using google forms and then published on the internet in a small group (30 student) in order to check the ease of performing it and if there is any problem about understanding the questions, after that it was published on a large scale and includes undergraduate pharmacy students, the results obtained from the pilot study were excluded from the major study.

Data entry and statistical analysis: Data were collected from the electronic response of the questionnaire and entered into Microsoft excel program, while Statistical analysis were performed using SPSS statistical package for Social Sciences (version 20.0 for windows, SPSS, Chicago, IL, USA).

Data are presented as mean \pm SD for quantitative variables and number with percentages for qualitative data. Relations were studied using Chi-square $\mathrm{X}^{2}$ test.P value of $<0.05$ was considered statistically significant.

\section{Results}

Two hundred and sixty pharmacy students accepted to participate in this study. The participants responded completely to the questionnaire. The demographic properties of the study population are shown in Table (1).

The age of the students was grouped as 16-20, 2125 and 26-30 years, and the main part of them were between $21-25$ years $(84.2 \%)$. Among the respondents $67.3 \%$ were female, and $32.7 \%$ were male.

About $2.7 \%$ of the respondents were first stage, $8.8 \%$ second stage, $9.6 \%$ third stage, $20.4 \%$ fourth stage, and $58.5 \%$ of them were fifth stage. Positive clinical 
orientation considered for $4^{\text {th }}$ and $5^{\text {th }}$ stage pharmacy students and represent $78.8 \%$ of the study population, $1^{\text {st }}, 2^{\text {nd }}$, and $3^{\text {rd }}$ stages were considered as negative clinical orientation they represent $21.2 \%$ of the study population.

Demographic characteristics of studied population sample (260 subjects):

\begin{tabular}{|c|c|c|c|}
\hline & & Count & $\%$ \\
\hline \multirow{2}{*}{ Gender } & Male & 85 & $32.7 \%$ \\
\hline & Female & 175 & $67.3 \%$ \\
\hline \multirow{3}{*}{ Age (Year) } & $16-20$ & 31 & $11.9 \%$ \\
\hline & $21-25$ & 219 & $84.2 \%$ \\
\hline & $26-30$ & 10 & $3.8 \%$ \\
\hline \multirow{5}{*}{ Year of undergraduate study } & First year & 7 & $2.7 \%$ \\
\hline & Second year & 23 & $8.8 \%$ \\
\hline & Third year & 25 & $9.6 \%$ \\
\hline & Fourth year & 53 & $20.4 \%$ \\
\hline & Fifth year & 152 & $58.5 \%$ \\
\hline \multirow{2}{*}{ Clinical orientation* } & Negative & 55 & $21.2 \%$ \\
\hline & Positive & 205 & $78.8 \%$ \\
\hline
\end{tabular}

*Negative clinical orientation was considered for first, second and third stage students.

*Positive clinical orientation was considered for fourth and fifth stage students.

Knowledge, awareness and attitude responses according to gender:

Knowledge: The responses of the students concerning knowledge of epilepsy are given in Figure 1 and table 2, Overall knowledge about epilepsy was moderate $(60.1 \pm 17.8)$, Majority of the students $75.4 \%$ answered that they know the cause of epilepsy. A higher percentage of respondents $(82.3 \%)$ said that epilepsy is not a contagious disease, About (54.6\%) of participants believed that epilepsy is inherited disease. Although (68.1\%) of respondents think that epilepsy is not caused by evil spirits, but (58\%) thought it is a form of mental illness, for this question we have significant relation between gender (male) and the base answer of this question, where the base answer of male students where significantly higher than those of female students (p-value $=0.034)$.

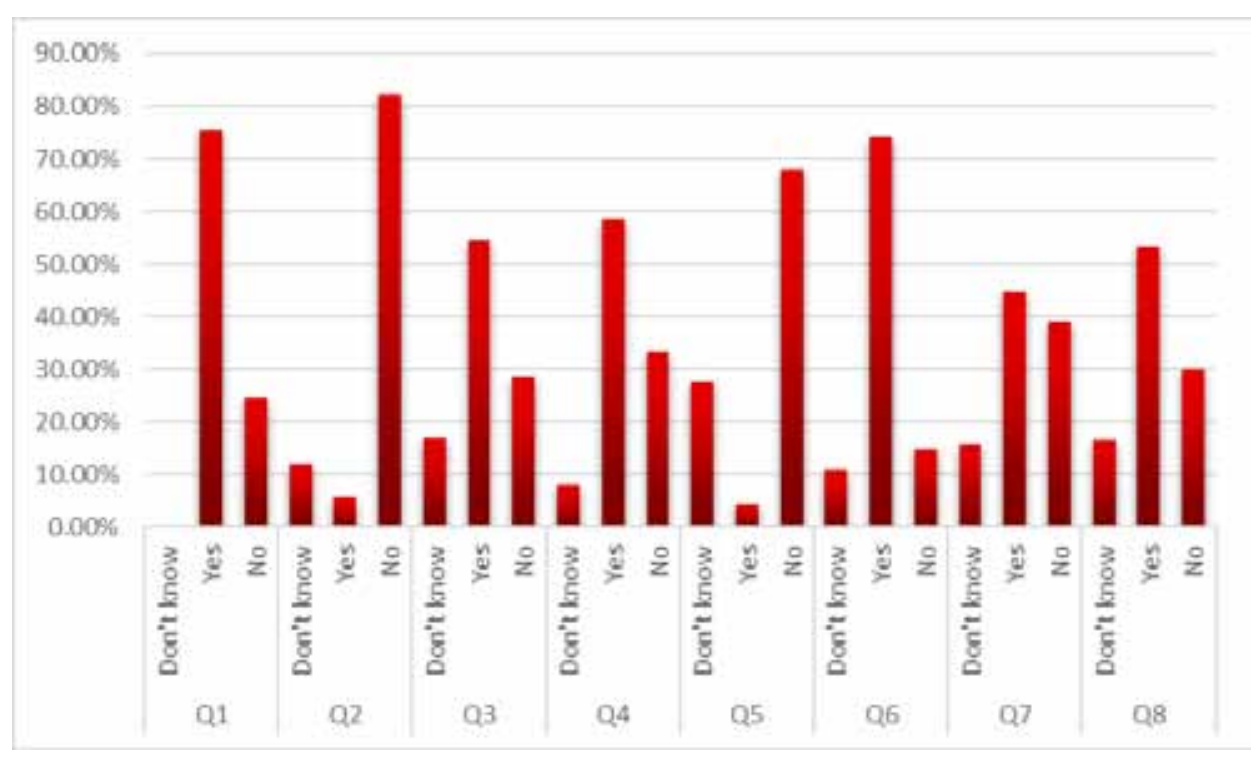

Figure 1: Knowledge response 
$74.2 \%$ of respondents thought that epileptic patients could die from seizures; however, (45\%) of the respondents thought that epilepsy is a curable disease. $53.5 \%$ of the students answered that they know how to perform first aid of epilepsy.

Awareness: The responses of students about awareness of epilepsy are presented in Figure 2 and table 2. The overall awareness response was poor $(42.6 \pm 33.5)$. The main part of the participants $(93.1 \%)$ said that they had heard or read about epilepsy, and (51.9\%) had attended a lecture or seminar about it for this question we have a significant relation between gender (female) and attendance a lecture or seminar about epilepsy.

Although $(86.5 \%)$ of the students said they had no epileptic patient in their family but $(43.5 \%)$ said that they have seen a person having epileptic attack with significant relation between gender (male) and seeing a person having epileptic attack. About (10.8\%) of study population had actually done first-aid seizure management.

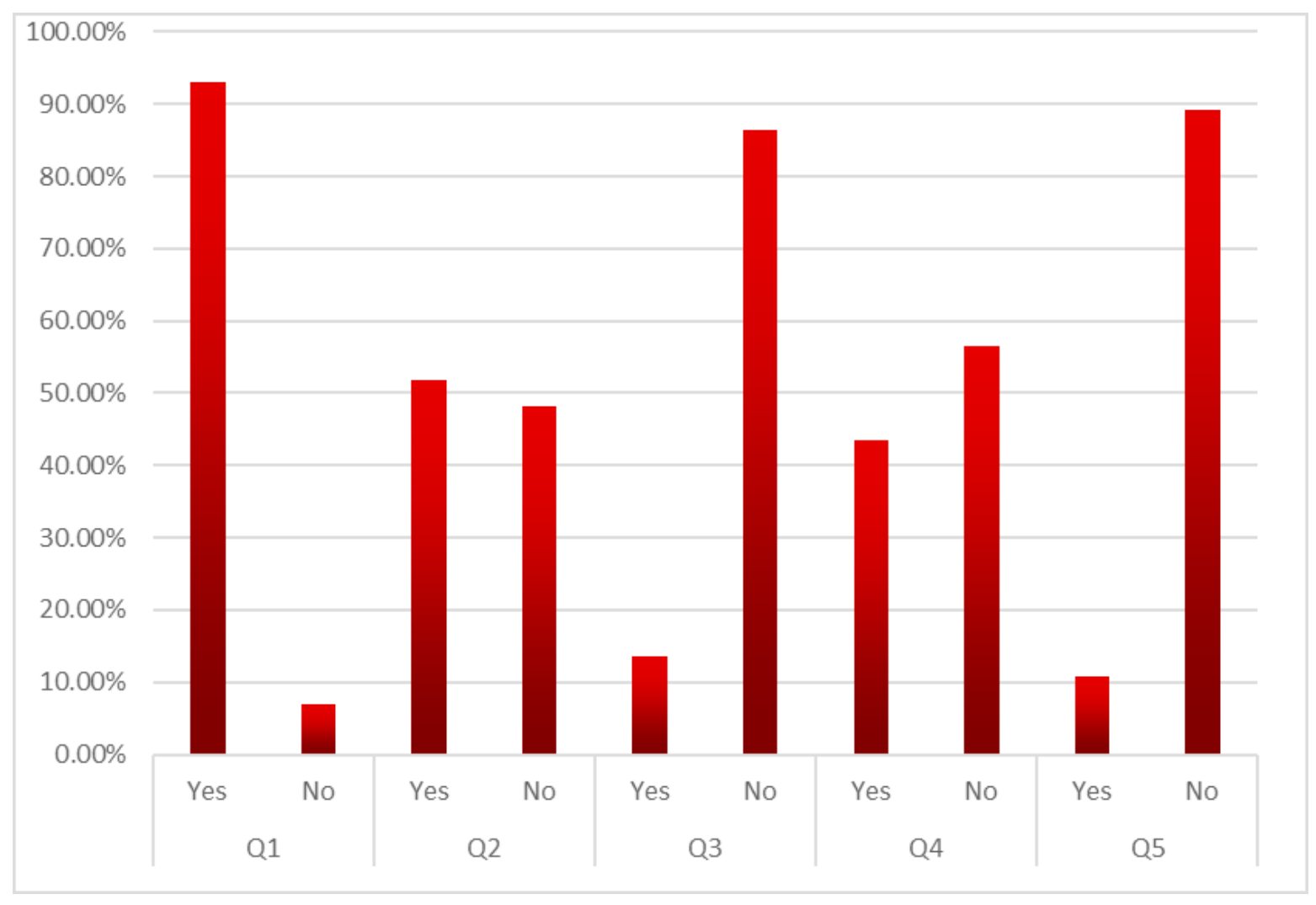

Figure 2: Awareness response

Attitude: The responses on attitudes to epilepsy are given in figures 3 and table 2 . The overall attitude was very good (83.3 \pm 13.1$)$.

The main part of the students (92.3\%) said epileptic patients could receive education and $89.6 \%$ of them said that epileptic patients could perform daily activities. Also $69.6 \%$ of them think that epileptic patients can participate in sports.
The main part of the students $(96.2 \%)$ thought epileptic patients should not be isolated from the normal population. About $(68.8 \%)$ of the respondents did not agree on dispensing of AEDs (Antiepileptic Drugs) by the pharmacist, with significant relation between gender(female) and the base answer of this question, where the female students were not agreed on dispensing AEDs by the pharmacist more than male students. 


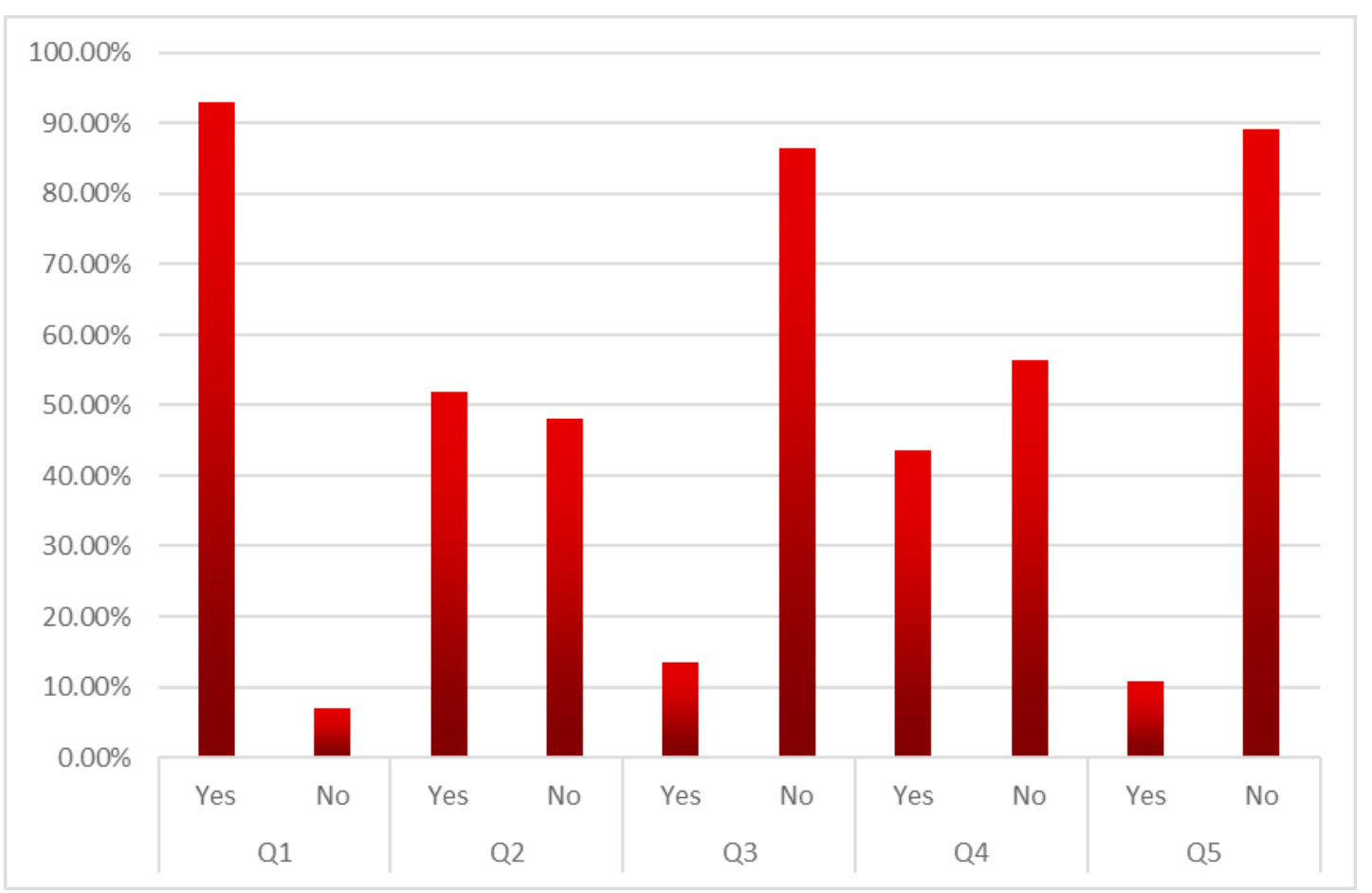

Figure 3: Attitude response

Knowledge, awareness and attitude responses according to gender:

\begin{tabular}{|c|c|c|c|c|}
\hline \multirow{2}{*}{\multicolumn{2}{|c|}{ Base answer }} & \multicolumn{2}{|c|}{ Gender } & \multirow{3}{*}{$\begin{array}{c}\text { Total } \\
\text { Count }(\%)\end{array}$} \\
\hline & & \multirow{2}{*}{$\begin{array}{c}\text { Male } \\
\text { Count (\%) }\end{array}$} & \multirow{2}{*}{$\begin{array}{c}\text { Female } \\
\text { Count }(\%) \\
\end{array}$} & \\
\hline & & & & \\
\hline Knowledge & $60.1 \pm 17.8$ & & & \\
\hline \multirow{3}{*}{$\begin{array}{l}\text { Do you know the cause of epilepsy } \\
\mathrm{X}^{2}=2.3, \mathrm{P}=0.167 \mathrm{NS}\end{array}$} & Don't know & 0 & 0 & 0 \\
\hline & Yes & $69(81.2)$ & $127(72.6)$ & $196(75.4)$ \\
\hline & No & $16(18.8)$ & $48(27.4)$ & $64(24.6)$ \\
\hline \multirow{3}{*}{$\begin{array}{l}\text { Do you think epilepsy is contagious } \\
\mathrm{X}^{2}=3.1, \mathrm{P}=0.213 \mathrm{NS}\end{array}$} & Don't know & $10(11.8)$ & $21(12.0)$ & $31(11.9)$ \\
\hline & Yes & $8(9.4)$ & $7(4.0)$ & $15(5.8)$ \\
\hline & No & $67(78.8)$ & $147(84.0)$ & $214(82.3)$ \\
\hline \multirow{3}{*}{$\begin{array}{l}\text { Do you think epilepsy is hereditary } \\
\mathrm{X}^{2}=4.1, \mathrm{P}=0.127 \mathrm{NS}\end{array}$} & Don't know & $10(11.8)$ & $34(19.4)$ & $44(16.9)$ \\
\hline & Yes & $45(52.9)$ & $97(55.4)$ & $142(54.6)$ \\
\hline & No & $30(35.3)$ & $44(25.1)$ & $74(28.5)$ \\
\hline \multirow{3}{*}{$\begin{array}{l}\text { Do you think epilepsy is a form mental illness } \\
\mathrm{X}^{2}=6.8, \mathrm{P}=0.034 \mathrm{~S}\end{array}$} & Don't know & $9(10.6)$ & $12(6.9)$ & $21(8.1)$ \\
\hline & Yes & $40(47.1)$ & $112(64.0)$ & $152(58.5)$ \\
\hline & No & $36(42.4)$ & $51(29.1)$ & $87(33.5)$ \\
\hline \multirow{3}{*}{$\begin{array}{l}\text { Do you think epilepsy is caused by evil spirits } \\
\mathrm{X}^{2}=2.8, \mathrm{P}=0.247 \mathrm{NS}\end{array}$} & Don't know & $21(24.7)$ & $51(29.1)$ & $72(27.7)$ \\
\hline & Yes & $6(7.1)$ & $5(2.9)$ & $11(4.2)$ \\
\hline & No & $58(68.2)$ & $119(68.0)$ & $177(68.1)$ \\
\hline \multirow{3}{*}{$\begin{array}{l}\text { Do you think people can die from seizures } \\
\mathrm{X}^{2}=2.8, \mathrm{P}=0.241 \mathrm{NS}\end{array}$} & Don't know & $6(7.1)$ & $22(12.6)$ & $28(10.8)$ \\
\hline & Yes & $63(74.1)$ & $130(74.3)$ & $193(74.2)$ \\
\hline & No & $16(18.8)$ & $23(13.1)$ & $39(15.0)$ \\
\hline
\end{tabular}




\begin{tabular}{|c|c|c|c|c|}
\hline \multirow{2}{*}{ Base answer } & & \multicolumn{2}{|c|}{ Gender } & \multirow{2}{*}{ Total } \\
\hline & & $\frac{\text { Male }}{\text { Count (\%) }}$ & $\frac{\text { Female }}{\text { Count }(\%)}$ & \\
\hline \multirow{3}{*}{$\begin{array}{l}\text { Do you think epilepsy can be cured } \\
\mathrm{X}^{2}=0.9, \mathrm{P}=0.625 \mathrm{NS}\end{array}$} & Don't know & $11(12.9)$ & $30(17.1)$ & $41(15.8)$ \\
\hline & Yes & $41(48.2)$ & $76(43.4)$ & $117(45.0)$ \\
\hline & No & $33(38.8)$ & $69(39.4)$ & $102(39.2)$ \\
\hline \multirow{3}{*}{$\begin{array}{l}\text { Do you know how to perform first-aid epilepsy } \\
\mathrm{X}^{2}=1.5, \mathrm{P}=0.475 \mathrm{NS}\end{array}$} & Don't know & $12(14.1)$ & $31(17.7)$ & $43(16.5)$ \\
\hline & Yes & $50(58.8)$ & $89(50.9)$ & $139(53.5)$ \\
\hline & No & $23(27.1)$ & $55(31.4)$ & $78(30.0)$ \\
\hline Awareness & \multicolumn{4}{|c|}{$42.6 \pm 33.5$} \\
\hline \multirow{2}{*}{$\begin{array}{l}\text { Have you heard or read about epilepsy } \\
\mathrm{X}^{2}=0.9, \mathrm{P}=0.326 \mathrm{NS}\end{array}$} & Yes & $81(95.3)$ & $161(92.0)$ & $242(93.1)$ \\
\hline & No & $4(4.7)$ & $14(8.0)$ & $18(6.9)$ \\
\hline \multirow{2}{*}{$\begin{array}{l}\text { Have you ever attended a lecture or seminar on } \\
\text { epilepsy } \\
\mathrm{X}^{2}=4.6, \mathrm{P}=0.031 \mathrm{~S}\end{array}$} & Yes & $36(42.4)$ & $99(56.6)$ & 135 (51.9) \\
\hline & No & $49(57.6)$ & $76(43.4)$ & $125(48.1)$ \\
\hline \multirow{2}{*}{$\begin{array}{l}\text { Anyone in your family that you know has epilepsy } \\
\mathrm{X}^{2}=0.05, \mathrm{P}=0.829 \mathrm{NS}\end{array}$} & Yes & $12(14.1)$ & $23(13.1)$ & $35(13.5)$ \\
\hline & No & $73(85.9)$ & $152(86.9)$ & $225(86.5)$ \\
\hline \multirow{2}{*}{$\begin{array}{l}\text { Have you ever seen anyone having epileptic attack } \\
\mathrm{X}^{2}=20.7, \mathrm{P}=0.005 \mathrm{~S}\end{array}$} & Yes & $54(63.5)$ & $59(33.7)$ & $113(43.5)$ \\
\hline & No & $31(36.5)$ & $116(66.3)$ & $147(56.5)$ \\
\hline \multirow{2}{*}{$\begin{array}{l}\text { Have you ever done first-aid seizure management } \\
\mathrm{X}^{2}=2.7, \mathrm{P}=0.101 \mathrm{NS}\end{array}$} & Yes & $13(15.3)$ & $15(8.6)$ & $28(10.8)$ \\
\hline & No & $72(84.7)$ & $160(91.4)$ & $232(89.2)$ \\
\hline Attitude & \multicolumn{4}{|c|}{$83.3 \pm 13.1$} \\
\hline \multirow{2}{*}{$\begin{array}{l}\text { Do you think epileptics can receive education } \\
\mathrm{X}^{2}=2.9, \mathrm{P}=0.086 \mathrm{NS}\end{array}$} & Yes & $75(88.2)$ & $165(94.3)$ & $240(92.3)$ \\
\hline & No & $10(11.8)$ & $10(5.7)$ & $20(7.7)$ \\
\hline \multirow{2}{*}{$\begin{array}{l}\text { Do you think epileptics can perform daily } \\
\text { activities } \\
\mathrm{X}^{2}=0.6, \mathrm{P}=0.429 \mathrm{NS}\end{array}$} & Yes & 78 (91.8) & $155(88.6)$ & $233(89.6)$ \\
\hline & No & $7(8.2)$ & $20(11.4)$ & $27(10.4)$ \\
\hline \multirow{2}{*}{$\begin{array}{l}\text { Do you think epileptics should not participate in } \\
\text { sports } \\
\mathrm{X}^{2}=0.8, \mathrm{P}=0.362 \mathrm{NS}\end{array}$} & Yes & $29(34.1)$ & $50(28.6)$ & $79(30.4)$ \\
\hline & No & $56(65.9)$ & $125(71.4)$ & $181(69.6)$ \\
\hline \multirow{2}{*}{$\begin{array}{l}\text { Do you think epileptics should be isolated from } \\
\text { normal population } \\
\mathrm{X}^{2}=1.4, \mathrm{P}=0.234 \mathrm{NS}\end{array}$} & Yes & $5(5.9)$ & $5(2.9)$ & $10(3.8)$ \\
\hline & No & $80(94.1)$ & $170(97.1)$ & $250(96.2)$ \\
\hline \multirow{2}{*}{$\begin{array}{l}\text { Do you think AEDs should be dispensed by } \\
\text { pharmacist } \\
\mathrm{X}^{2}=4.6, \mathrm{P}=0.032 \mathrm{~S}\end{array}$} & Yes & $34(40.0)$ & $47(26.9)$ & $81(31.2)$ \\
\hline & No & $51(60.0)$ & $128(73.1)$ & $179(68.8)$ \\
\hline
\end{tabular}

Base answers (Yes/No) are in bold format showing mean \pm SD for Knowledge, awareness and attitude responses

NS: No significant relation to gender

Significant relation using Chi-square test to gender were detected in Knowledge Q4 $(\mathrm{P}=0.034)$, Awareness Q2 $(\mathrm{P}=0.031)$ and $\mathrm{Q} 4(\mathrm{P}=0.005)$, and Attitude Q5 $(\mathrm{P}=0.032)$.
Knowledge, awareness and attitude responses according to clinical orientation: Are presented in table 3, Negative clinical orientation was considered for first, second and third stage students. while Positive clinical orientation was considered for fourth and fifth stage students.

Knowledge: According to the question "Do you know the cause of epilepsy?" There was a significant relation between the clinical orientation (positive) and 
the base answer of this question. There is no significant differences between positive and negative clinical orientation for all other questions.

Awareness: According to the question about the attendance a lecture or seminar on epilepsy, there was a significant relation between the clinical orientation (positive) and the base answer of this question.
Attitudes: According to the question about the dispensing of AEDs by pharmacist there was a significant relation between the clinical orientation (positive) and the base answer of this question.

Knowledge, awareness and attitude responses according to clinical orientation:

\begin{tabular}{|c|c|c|c|c|}
\hline \multirow{2}{*}{ Base answer } & & \multicolumn{2}{|c|}{ Clinical orientation } & \multirow{2}{*}{ Total } \\
\hline & & \multirow{2}{*}{$\begin{array}{c}\text { Negative } \\
\text { Count (\%) }\end{array}$} & \multirow{2}{*}{$\begin{array}{c}\text { Positive } \\
\text { Count (\%) }\end{array}$} & \\
\hline & & & & \\
\hline Knowledge & $60.1 \pm 17.8$ & & & \\
\hline \multirow{3}{*}{$\begin{array}{l}\text { Do you know the cause of epilepsy } \\
\mathrm{X}^{2}=11.1, \mathrm{P}=0.001 \mathrm{~S}\end{array}$} & Don't know & 0 & 0 & 0 \\
\hline & Yes & $32(58.2)$ & $164(80.0)$ & $196(75.4)$ \\
\hline & No & $23(41.8)$ & $41(20.0)$ & $64(24.6)$ \\
\hline \multirow{3}{*}{$\begin{array}{l}\text { Do you think epilepsy is contagious } \\
\mathrm{X}^{2}=0.33, \mathrm{P}=0.846 \mathrm{NS}\end{array}$} & Don't know & $6(10.9)$ & $25(12.2)$ & $31(11.9)$ \\
\hline & Yes & $4(7.3)$ & $11(5.4)$ & $15(5.8)$ \\
\hline & No & $45(81.8)$ & $169(82.4)$ & $214(82.3)$ \\
\hline \multirow{3}{*}{$\begin{array}{l}\text { Do you think epilepsy is hereditary } \\
\mathrm{X}^{2}=0.93, \mathrm{P}=0.629 \mathrm{NS}\end{array}$} & Don't know & $11(20.0)$ & $33(16.1)$ & $44(16.9)$ \\
\hline & Yes & $27(49.1)$ & $115(56.1)$ & $142(54.6)$ \\
\hline & No & $17(30.9)$ & $57(27.8)$ & $74(28.5)$ \\
\hline \multirow{3}{*}{$\begin{array}{l}\text { Do you think epilepsy is a form mental illness } \\
\mathrm{X}^{2}=3.3, \mathrm{P}=0.194 \mathrm{NS}\end{array}$} & Don't know & $3(5.5)$ & $18(8.8)$ & $21(8.1)$ \\
\hline & Yes & $38(69.1)$ & $114(55.6)$ & $152(58.5)$ \\
\hline & No & $14(25.5)$ & $73(35.6)$ & $87(33.5)$ \\
\hline \multirow{3}{*}{$\begin{array}{l}\text { Do you think epilepsy is caused by evil spirits } \\
\mathrm{X}^{2}=1.9, \mathrm{P}=0.377 \mathrm{NS}\end{array}$} & Don't know & $13(23.6)$ & $59(28.8)$ & $72(27.7)$ \\
\hline & Yes & $4(7.3)$ & $7(3.4)$ & $11(4.2)$ \\
\hline & No & $38(69.1)$ & $139(67.8)$ & $177(68.1)$ \\
\hline \multirow{3}{*}{$\begin{array}{l}\text { Do you think people can die from seizures } \\
\mathrm{X}^{2}=0.27, \mathrm{P}=0.874 \mathrm{NS}\end{array}$} & Don't know & $5(9.1)$ & $23(11.2)$ & $28(10.8)$ \\
\hline & Yes & $41(74.5)$ & $152(74.1)$ & $193(74.2)$ \\
\hline & No & $9(16.4)$ & $30(14.6)$ & $39(15.0)$ \\
\hline \multirow{3}{*}{$\begin{array}{l}\text { Do you think epilepsy can be cured } \\
\mathrm{X}^{2}=0.41, \mathrm{P}=0.816 \mathrm{NS}\end{array}$} & Don’t know & $10(18.2)$ & $31(15.1)$ & $41(15.8)$ \\
\hline & Yes & $25(45.5)$ & $92(44.9)$ & $117(45.0)$ \\
\hline & No & $20(36.4)$ & $82(40.0)$ & $102(39.2)$ \\
\hline \multirow{3}{*}{$\begin{array}{l}\text { Do you know how to perform first-aid epilepsy } \\
\mathrm{X}^{2}=1.7, \mathrm{P}=0.429 \mathrm{NS}\end{array}$} & Don't know & $12(21.8)$ & $31(15.1)$ & $43(16.5)$ \\
\hline & Yes & $26(47.3)$ & $113(55.1)$ & $139(53.5)$ \\
\hline & No & $17(30.9)$ & $61(29.8)$ & $78(30.0)$ \\
\hline Awareness & $42.6 \pm 33.5$ & & & \\
\hline \multirow{2}{*}{$\begin{array}{l}\text { Have you heard or read about epilepsy } \\
\mathrm{X}^{2}=0.51, \mathrm{P}=0.548 \mathrm{NS}\end{array}$} & Yes & $50(90.9)$ & $192(93.7)$ & $242(93.1)$ \\
\hline & No & $5(9.1)$ & $13(6.3)$ & $18(6.9)$ \\
\hline \multirow{2}{*}{$\begin{array}{l}\text { Have you ever attended a lecture or seminar on } \\
\text { epilepsy } \\
\mathrm{X}^{2}=22.4, \mathrm{P}=0.005 \mathrm{~S}\end{array}$} & Yes & $13(23.6)$ & $122(59.5)$ & $135(51.9)$ \\
\hline & No & $42(76.4)$ & $83(40.5)$ & $125(48.1)$ \\
\hline
\end{tabular}




\begin{tabular}{|c|c|c|c|c|}
\hline \multirow{2}{*}{\multicolumn{2}{|c|}{ Base answer }} & \multicolumn{2}{|c|}{ Clinical orientation } & \multirow{2}{*}{$\begin{array}{c}\text { Total } \\
\text { Count }(\%) \\
\end{array}$} \\
\hline & & $\begin{array}{c}\text { Negative } \\
\text { Count (\%) }\end{array}$ & $\begin{array}{c}\text { Positive } \\
\text { Count (\%) }\end{array}$ & \\
\hline \multirow{3}{*}{$\begin{array}{l}\text { Anyone in your family that you know has epilepsy } \\
\mathrm{X}^{2}=2.3, \mathrm{P}=0.130 \mathrm{NS}\end{array}$} & & & & \\
\hline & Yes & $4(7.3)$ & $31(15.1)$ & $35(13.5)$ \\
\hline & No & $51(92.7)$ & $174(84.9)$ & $225(86.5)$ \\
\hline \multirow{2}{*}{$\begin{array}{l}\text { Have you ever seen anyone having epileptic attack } \\
\mathrm{X}^{2}=0.41, \mathrm{P}=0.521 \mathrm{NS}\end{array}$} & Yes & $26(47.3)$ & $87(42.4)$ & $113(43.5)$ \\
\hline & No & $29(52.7)$ & $118(57.6)$ & $147(56.5)$ \\
\hline \multirow{2}{*}{$\begin{array}{l}\text { Have you ever done first-aid seizure management } \\
\mathrm{X}^{2}=0.001, \mathrm{P}=0.970 \mathrm{NS}\end{array}$} & Yes & $6(10.9)$ & $22(10.7)$ & $28(10.8)$ \\
\hline & No & $49(89.1)$ & $183(89.3)$ & $232(89.2)$ \\
\hline Attitude & $83.3 \pm 13.1$ & & & \\
\hline \multirow{2}{*}{$\begin{array}{l}\text { Do you think epileptics can receive education } \\
\mathrm{X}^{2}=1.01, \mathrm{P}=0.313 \mathrm{NS}\end{array}$} & Yes & $49(89.1)$ & $191(93.2)$ & $240(92.3)$ \\
\hline & No & $6(10.9)$ & $14(6.8)$ & $20(7.7)$ \\
\hline \multirow{2}{*}{$\begin{array}{l}\text { Do you think epileptics can perform daily } \\
\text { activities } \\
\mathrm{X}^{2}=1.3, \mathrm{P}=0.255 \mathrm{NS}\end{array}$} & Yes & $47(85.5)$ & $186(90.7)$ & $233(89.6)$ \\
\hline & No & $8(14.5)$ & $19(9.3)$ & $27(10.4)$ \\
\hline \multirow{2}{*}{$\begin{array}{l}\text { Do you think epileptics should not participate in } \\
\text { sports } \\
\mathrm{X}^{2}=0.80, \mathrm{P}=0.371 \mathrm{NS}\end{array}$} & Yes & $14(25.5)$ & $65(31.7)$ & $79(30.4)$ \\
\hline & No & $41(74.5)$ & $140(68.3)$ & $181(69.6)$ \\
\hline \multirow{2}{*}{$\begin{array}{l}\text { Do you think epileptics should be isolated from } \\
\text { normal population } \\
\mathrm{X}^{2}=2.2, \mathrm{P}=0.137 \mathrm{NS}\end{array}$} & Yes & $4(7.3)$ & $6(2.9)$ & $10(3.8)$ \\
\hline & No & $51(92.7)$ & $199(97.1)$ & $250(96.2)$ \\
\hline \multirow{2}{*}{$\begin{array}{l}\text { Do you think AEDs should be dispensed by } \\
\text { pharmacist } \\
X^{2}=20.7, P=0.005 \mathrm{~S}\end{array}$} & Yes & $31(56.4)$ & $50(24.4)$ & $81(31.2)$ \\
\hline & No & $24(43.6)$ & $155(75.6)$ & $179(68.8)$ \\
\hline
\end{tabular}

Base answers (Yes/No) are in bold format showing mean \pm SD for Knowledge, awareness and attitude responses

\section{NS: No significant relation to gender}

Significant relation using Chi-square test to clinical orientation were detected in Knowledge Q1 $(\mathrm{P}=0.001)$, Awareness Q2 ( $\mathrm{P}=0.005)$, and Attitude Q5 ( $\mathrm{P}=0.005)$.

\section{Discussion}

The present study was accomplished to evaluate knowledge, awareness and attitude towards epilepsy among undergraduate pharmacy students. Pharmacists have an executive obligation to give information, advice and direction to their patients ${ }^{(32)}$, including those using AEDs.

The female percentage participated in the present study was more than male percentage, which is attributed to the higher number of females than males in most of the Iraqi pharmacy colleges.
In the present study, the main part of the students (75.4\%) said they knew the cause of epilepsy. This percentage is approximately more compared to study done on pharmacy students in University of Karachi, Pakistan $(68.5 \%)^{(17)}$.

For the question "do you think epilepsy is contagious?" our results

Showed that $82.3 \%$ of the participants knew it is not contagious, while the percentage of participants who think the same in different universities in Pakistan for pharmacy students was $84.2 \%{ }^{(25)}$. However, in a study done among school teachers in Bobo-Dioulasso the percentage was $73.8 \%{ }^{(26)}$ and the percentage of other study done among students of other colleges in a Malaysian university was $84 \%{ }^{(27)}$, while in Zimbabwe a study done on teachers show a percentage about $71.1 \%{ }^{(28)}$, This result could be related to the fact that more knowledge about diseases is obtained throughout the study in pharmacy colleges than in other different colleges. 
About $54.6 \%$ of the participants of the present study said epilepsy is hereditary, A study done among pharmacy students from Pakistan reported that $70 \%$ of the students know the hereditary nature of epilepsy, while other study done in the university of Mumbai showed that all the participants thought epilepsy is not hereditary ${ }^{(16,17)}$,in a study done among public in Jordan, the percentage of people who think epilepsy is an inherited disease was $43.5 \%{ }^{(29)}$. These difference could have originated as there was conflicting evidence regarding hereditary nature of epilepsy, but the recent research improve this where the development in genetic technology has led to the identification of an increasing number of genes associated with epilepsy ${ }^{(30)}$.

$58 \%$ of the participants from the present study believed that epilepsy is a form of mental illness. This percentage is much lower than the study done in Mumbai-India (98\%), and higher than that of students in a Malaysian university $(39.7 \%){ }^{(16,27)}$, so our result is confusing since pharmacy students should know that epilepsy is not a mental disease instead, rather it is neurological, for this question we show significant relation between gender (male) and the base answer of the question, where $42.2 \%$ of male students said that epilepsy is not a form of mental illness compared with $29.1 \%$ of female students of same answer, by comparing with the result of a study from Mumbai university that showed no significant difference between males and females about knowledge about epilepsy ${ }^{(16)}$.

In the present study, only 139 out of 260 (53.5\%) knew how to perform first-aid in epilepsy. A similar study done on pharmacy students from Karachi reported 33\% of the participants knowing first aid in epilepsy, while in Mumbai study the percentage was only $0.98 \%(16,17)$, this considered a very good result for Iraqi pharmacy students.

The present study showed that about $93.1 \%$ of the students had heard or read about epilepsy. This was relatively higher compared to those reported among pharmacy students from Pakistan university (89.8\%), but lower than those of pharmacy students in Mumbai university $(96 \%){ }^{(16,17)}$.

While in a study done among students in Malaysian university the percentage was $86.5 \%{ }^{(27)}$.Also the present study showed that $51.9 \%$ of the participants had attended a lecture or seminar on epilepsy, with significant relation with female than male students, where $56.6 \%$ of female attended a lecture or seminar on epilepsy compared with $42.4 \%$ of male students, by comparing with the results of Malaysian study that showed only $2.4 \%$ of the participants attended a lecture or seminar on epilepsy (27), while another study in Mumbai university showed that $97 \%$ of the participants attended a lecture or seminar on epilepsy with no significant differences between male and female students ${ }^{(16)}$.

$43.5 \%$ of the participants of the present study had seen someone having epileptic attack, with significant relation to male than female students, where the male percentage was $63.5 \%$ while female percentage was $33.7 \%$, a study done in Pakistan showed that $54 \%$ of study population had seen an epileptic seizure ${ }^{(17)}$.

$31.2 \%$ of the participants believed that anti-epileptic drugs should be dispensed by pharmacist without a valid prescription. This was unexpected as pharmacy students study drug rules and they are expected to know that antiepileptic drugs in Iraq dispensed only after presenting valid physician prescription.

Knowledge, awareness and attitude responses according to clinical orientation: are presented in (table 3)

According to the question "Do you know the cause of epilepsy?" There was a significant relation between the clinical orientation (positive) and the base answer of this question (p-value 0.001 ), where $80 \%$ of the students of positive clinical orientation ( $4^{\text {th }}$ and $5^{\text {th }}$ stages) knew the cause of epilepsy comparing with $58.2 \%$ of the students of negative clinical orientation $\left(1^{\text {st }}, 2^{\text {nd }}\right.$ and $\left.3^{\text {rd }}\right)$, also we showed a significant difference between them ( $p$-value 0.005 ) for attendance a lecture or seminar on epilepsy, where $59.5 \%$ of positive clinical students compared to only $23.6 \%$ of negative clinical students had attended a lecture or seminar on epilepsy.

Also $75.6 \%$ of positive clinical compared with $43.6 \%$ of those negative clinical students believed that anti-epileptic drugs should not be dispensed by pharmacist without a valid prescription ( $p$-value 0.005 ), by comparing with saudi study that showed the same results where it showed that there was a greater level of knowledge and attitude toward epilepsy among clinicalyear students compared to preclinical-year students ${ }^{(31)}$, this could be related to the fact that more knowledge about epilepsy is obtained throughout the study in fourth and fifth stages where the curriculum in Iraqi pharmacy colleges involve clinical pharmacy and hospital training in those 2 stages compared to the first 3 stages. 


\section{Conclusion}

The results of the present study identify the shortage of pharmacy students towards epilepsy knowledge and awareness. However, the majority of participants had positive attitudes towards it. Also a lot of students thought epilepsy is a form of mental diseases which refers to lack of knowledge. In addition, some of the pharmacy students in this study believed in the necessity of dispensing antiepileptic drugs by pharmacist.

There is a need to improve certain aspects of knowledge and awareness, understanding of epilepsy among pharmacy students especially for those selecting their career as clinical pharmacist.

Ethical Clearance: All the students included in this study were of age 18 years and older, and they reveal voluntary permission to participation. There were no personal identifiers during the administration and collection of the questionnaire to rule out any personal identification.

\section{Source of Funding: Self}

Conflict of Interest: There is no conflict of interest

\section{References}

1. Nimesh S. A pharmacovigilance study of monitoring \& focusing of adverse drug reactions induced by antiepileptic drugs used in epileptic patients. Pharm Pharmacol Int J. 2019;7(3):100-4.

2. Khudhur IA, Mehabes FJ. Impact of epilepsy on patient's physical and psychosocial functioning.

3. Al-Asfoor AR, Al Mousawi A, Al Haydari A. Comorbidity of Epilepsy and Depression in Al Husseini Teaching Hospital in Holy Kerbala/ Iraq in 2018. Karbala Journal of Medicine. 2020;13(1):2310-8.

4. Marie A. Chisholm- Burns. Pharmaco- therapy Principles and Practice. 4th edition 2016. p: 477.

5. Dahl-Hansen E, Koht J, Syvertsen M. Epilepsy at different ages-Etiologies in a Norwegian population. Epilepsia Open. 2019 Mar;4(1):17681.

6. Fiest KM, Sauro KM, Wiebe S, et al. Prevalence and incidence of epilepsy: a systematic review and meta-analysis of international studies. Neurology. 2017 Jan 17;88(3):296-303.

7. Thurman DJ, Begley CE, Carpio A, et al. The primary prevention of epilepsy: A report of the Prevention Task Force of the International League Against Epilepsy. Epilepsia. 2018 May;59(5):90514.

8. Tedrus GM, Fonseca LC, Vieira AL. Knowledge and attitudes toward epilepsy amongst students in the health area: intervention aimed at enlightenment. Arquivos de Neuro-psiquiatria. 2007 Dec;65(4B):1181-5.

9. Aldenkamp AP, Weber B, Overweg-Plandsoen $\mathrm{WC}$, et al. Educational underachievement in children with epilepsy: a model to predict the effects of epilepsy on educational achievement. Journal of Child Neurology. 2005 Mar;20(3):175-80.

10. Elwes RD, Marshall J, Beattie A, et al. Epilepsy and employment. A community based survey in an area of high unemployment. Journal of Neurology, Neurosurgery \& Psychiatry. 1991 Mar 1;54(3):2003.

11. Sadr SS, Javanbakht J, Javidan AN, et al. Descriptive epidemiology: prevalence, incidence, sociodemographic factors, socioeconomic domains, and quality of life of epilepsy: an update and systematic review. Archives of medical science: AMS. 2018 Jun;14(4):717.

12. Scambler G, Hopkins A. Being epileptic: coming to terms with stigma. Sociology of health \& illness. 1986 Mar;8(1):26-43.

13. Shetty PH, Naik RK, Saroja AO, et al. Quality of life in patients with epilepsy in India. Journal of neurosciences in rural practice. $2011 \mathrm{Jan} ; 2(1): 33$.

14. Long L, Reeves AL, Moore JL, et al. An assessment of epilepsy patients' knowledge of their disorder. Epilepsia. 2000 Jun;41(6):727-31.

15. Doughty J, Baker GA, Jacoby A, et al. Crosscultural differences in levels of knowledge about epilepsy. Epilepsia. 2003 Jan;44(1):115-23.

16. Limaye D, Deshpande O, Gite P, et al. Knowledge and attitude towards epilepsy among pharmacy students from Mumbai university.

17. Hasan SS, Khan MH. Knowledge, awareness and attitudes of pharmacy students toward epilepsy. Pharmacy Education. 2011;11.

18. Bener A, Al-Marzooqi FH, Sztriha L. Public awareness and attitudes towards epilepsy in the United Arab Emirates. Seizure. 1998 Jun $1 ; 7(3): 219-22$. 
19. Al-Dossari KK, Al-Ghamdi S, Al-Zahrani J, et al. Public knowledge awareness and attitudes toward epilepsy in Al-Kharj Governorate Saudi Arabia. Journal of family medicine and primary care. 2018 Jan;7(1): 184 .

20. Awad A, Sarkhoo F. Public knowledge and attitudes toward epilepsy in Kuwait. Epilepsia. 2008 Apr;49(4):564-72.

21. Young GB, Derry P, Hutchinson I, et al. An epilepsy questionnaire study of knowledge and attitudes in Canadian college students. Epilepsia. 2002 Jun;43(6):652-8.

22. Al-Rashed H, Al-Yahya D, Al-Kandari A, et al. Knowledge of, perceptions of, and attitudes toward epilepsy among university students in Kuwait. Epilepsy \& Behavior. 2009 Feb 1;14(2):367-71.

23. Caveness WF, Gallup Jr GH. A survey of public attitudes toward epilepsy in 1979 with an indication of trends over the past thirty years. Epilepsia. 1980 Oct;21(5):509-18.

24. Macit C, Clark PM, Taner N, et al. A survey on awareness, knowledge, and attitudes toward epilepsy in an urban community in Turkey. Nigerian journal of clinical practice. 2018;21(8):979-87.

25. Anjum F, Ghayas S, Ali T, et al. Awareness of epilepsy in pharmacy students in different universities of Karachi, Pakistan. African Journal of Pharmacy and Pharmacology. 2014 Mar 15;8(10):278-83.
26. Millogo A, Siranyan AS. Knowledge of epilepsy and attitudes towards the condition among schoolteachers in Bobo-Dioulasso (Burkina Faso). Epileptic disorders. 2004 Mar 1;6(1):21-6.

27. Ab Rahman AF. Awareness and knowledge of epilepsy among students in a Malaysian university. Seizure: European Journal of Epilepsy. 2005 Dec;14(8):593-6.

28. Mielke J, Adamolekun B, Ball D, et al. Knowledge and attitudes of teachers towards epilepsy in Zimbabwe. Acta Neurologica Scandinavica. 1997 Sep;96(3):133-7.

29. Daoud A, Al-Safi S, Otoom S, et al. Public knowledge and attitudes towards epilepsy in Jordan. Seizure. 2007 Sep 1;16(6):521-6.

30. Jie Wanga, Zhi-Jian Lina, Liu Liua, et al. Epilepsyassociated genes. Seizure 44 (2017) 11-20.

31. Alomar S, Kadi M, Alabbas D, et al. Awareness and attitudes toward epilepsy among medical and allied healthcare students - A survey study in a teaching hospital in Jeddah. Epilepsy \& Behavior. 2020 Jan 1;102:106815.

32. Mohammed SI, Al-Shadedi MI, Kasim AA. Knowledge, Use and Recommendation of Iraqi Pharmacist Toward Complementary and Alternative Medicine. Iraqi Journal of Pharmaceutical Sciences (P-ISSN: 1683-3597, E-ISSN: 2521-3512). 2020 Jun 21;29(1):88-93. 